\title{
Parasitism and invasive species: effects of digenetic trematodes on mussels
}

\author{
G. Calvo-Ugarteburu, C. D. McQuaid* \\ Department of Zoology and Entomology, Rhodes University, Grahamstown 6140, South Africa
}

\begin{abstract}
The brown mussel Perna perna in South Africa is threatened by the introduction of the invasive Mediterranean mussel Mytilus galloprovincialis. Whilst the indigenous P. perna has been found to be commonly infected by digenetic trematodes, the invasive $M$. galloprovincialis is free of trematodes, which may give it a competitive advantage in direct or indirect interactions between the 2 mussels. The most common parasites infecting $P$. perna are 2 species of digenetic trematodes: metacercariae of the genus Proctoeces and bucephalid sporocysts. The influence of these 2 parasites on the ecological fitness of their host was tested by examining their effects on survival and competitive ability of $P$ perna. The results showed significant negative effects. Both parasites significantly depressed condition, but only after spawning, when the mussels were already stressed. Neither parasite affected mortality rate or gaping behaviour of $P$. perna exposed to air. Proctoeces did not affect the force required to open mussels or the amount of water lost by mussels in air In contrast, mussels infected with bucephalid sporocysts were easier to open and lost significantly more water than non-infected individuals, possibly because their valves did not seal properly. There were no significant differences in either number or size of oocytes in females infected with Proctoeces compared with non-infected females. However, bucephalid sporocysts had a dramatic effect on reproduction by castrating the host. Proctoeces reduced growth both in summer and in winter, whilst bucephalid sporocysts had no significant effect on growth. Neither parasite had a significant effect on filtration rates or oxygen consumption of the host. All these results indicate that both Proctoeces and the bucephalid sporocysts have detrimental effects on $P$. perna. Proctoeces affects primarily growth, while bucephalid sporocysts affect reproduction, adductor muscle strength and water loss. The effects of both parasites are concentrated on those size classes of mussel which channel most energy into the portion of the energy budget affected by the parasite. Proctoeces affects growth only in the smaller individuals, which in normal conditions would put most energy into growth; bucephalid sporocysts castrate the bigger mussels, which would expend most energy on reproduction. In energetic terms, the absence of effects on filtration and respiration indicates that there was neither re-allocation nor compensation for the energy lost from production, but that it was simply re-routed to the parasite. These negative effects, together with the high prevalence of both parasites in P. perna along the South African coast and their absence in $M$. galloprovincialis, suggest that lack of these parasites may contribute to the success of $M$. galloprovincialis.
\end{abstract}

KEY WORDS: Mussels - Invasive - Indigenous - Trematodes Ecological fitness Condition Water loss Survival Adductor muscie strength Reproduction Growth Filtration-Respiration

\section{INTRODUCTION}

The importance of parasites as potential regulatory agents of populations has long been controversial. Since the suggestion of Anderson \& May in the late 1970 s that parasites can regulate host populations (Anderson \& May 1978, May \& Anderson 1978), many

\footnotetext{
-Addressee for correspondence.
}

E-mail: zocm@hippo.ru.ac.za authors have shown that macroparasites can regulate host population abundance (Anderson 1978, Anderson \& Crombie 1984, Scott \& Anderson 1984, Blower \& Roughgarden 1987, also see Kuris 1974). Not only can parasites regulate host populations, they can also affect host behaviour (reviewed by Poulin 1994), resulting in a decrease in fitness in most cases.

Despite this many authors have noticed a lack of ecological perspective in parasitological studies (Cheng 1967. Kinne 1983, Huxham et al. 1993). Likewise, ecol- 
ogists usually ignore the effects of parasites, and Lauckner (1986) goes so far as to question the validity of many marine ecological studies since they neglect the effects of larval digeneans on the ecosystem. Nevertheless, in the last few years there has been a considerable increase in this type of study. Many examples of how parasites may alter the behaviour of their host in such a way as to leave it more vulnerable to predators are provided in a book edited by Barnard \& Behnke (1990) using examples from both terrestrial and aquatic ecosystems. Two typical marine cases are those described by Granovitch (1992) and Jonsonn \& Andre (1992). Granovitch showed that trematodes affect the migration patterns of the intertidal snail Littorina saxatilis, preventing it from making its normal tidal migrations. Those snails that do not migrate during low tides are much more susceptible to predation by birds. Jonsonn \& Andre found a correlation between digenetic trematode infection and loss of burrowing ability in the cockle Cerastoderma edule. Again, this impaired burrowing ability increased the susceptibility of cockles to predators. Price et al. (1986) reviewed differenl ways in which parasitism may affect the outcome of competition, and concluded that mediation by parasites is very common in nature and must be regarded as one of the major types of interaction in ecological systems.

A second question ecologists have busied themselves with for many years is that of biological invasions (e.g. Macdonald et al. 1986, Mooney \& Drake 1986, Drake et al. 1989, Hengeveld 1989, Ramakrishnan 1991). The introduction of a new organism into an ecosystem usually creates general concern about its effects on the native biota. Aliens may influence the community by changing species diversity, community structure and function and/or the ecological processes that are dependent on the interaction between organisms, e.g. competition (Breytenbach 1986, Bruton \& van As 1986, Ramakrishnan \& Vitousek 1989). Competition between indigenous and introduced species is central to the study of biological invasions, and it has been suggested that parasite release is important in allowing an introduced species to become invasive (Bruton 1986)

The Mediterranean mussel Mytilus galloprovincialis was accidentally introduced to South Africa in the late 1970 s (Grant \& Cherry 1985), and it has since become invasive (van Erkom Schurink \& Griffiths 1990, Hockey \& van Erkom Schurink 1992). Griffiths et al. (1992) estimated that $M$. galloprovincialis constituted over $70 \%$ of the intertidal mussel biomass on the west coast of South Africa, having displaced the slowergrowing Aulacomya ater. It is now spreading rapidly onto the south and east coasts (Phillips 1994), where it has the potential to compete with the indigenous mus- sel Perna perna (van Erkom Schurink \& Griffiths 1990). Comparative studies performed by van Erkom Schurink \& Griffiths $(1991,1993)$ and Hockey \& van Erkom Schurink (1992) on the 4 major species of mussels present in South Africa nowadays indicate that $M$. galloprovincialis exhibits all the characteristics of an aggressive invasive species: it has a rapid growth rate under a wide range of environmental conditions, a high level of tolerance to physiologically limiting factors, which allows it to colonize marginal areas, and a higher reproductive potential than the 3 indigenous species have. All these characteristics have been considered by Ehrlich (1989) as attributes of a successful invasive.

Parasitic infections have been recognized as one of a number of stressful factors which may lower the resistance of the host and its ability to adapt to changing environmental conditions (Williams \& Jones 1994). Whether the reason for the success of Mytilus galloprovincialis is its competitive superiority or its lack of parasites, there is no doubt that this species has become successfully established on the west coast of South Africa and has the potential to displace the indigenous Perna perna on the south and east coasts.

This paper is part of a broader study which attempts to bring together the topics of parasitology and marine ecology. In a previous paper (Calvo-Ugarteburu \& McQuaid 1998) we have shown that the indigenous mussel Perna perna in South Africa is commonly infected by digenetic trematodes whilst the invasive Mytilus galloprovincialis is free of trematodes. The most common trematode species found in $P$. perna are metacercariae of the genus Proctoeces and bucephalid sporocysts, with infection rates of up to 62 and $49 \%$ respectively. Detailed information about these 2 digenean species will be given in a separate paper (Calvo-Ugarteburu \& McQuaid unpubl.). The present paper attempts to assess the effects of these 2 digenetic trematodes on the survival and competitive ability of $P$. perna. A next step to be considered would be competition experiments between infected $P$. perna and non-infected $M$. galloprovincialis in an attempt to examine specific mechanisms by which parasites may affect interactions between both species of mussels as a possible example of parasite mediated competition.

The first part of this paper deals with the effects of both parasites on host survival, comparing mortality rates of infected and non-infected individuals under normal and stressful conditions. The effects of the parasites on factors that may indirectly affect survival, such as general condition, water loss and adductor mussel strength, are also considered. In the second part, the effect of the parasites on the competitive ability of their host is studied. One of the major factors shaping the composition of a mussel bed is competition 
for space and food, with slower-growing mussels being at a competitive disadvantage (Kautsky 1982). In order to examine the effects of both parasites on the competitive ability of Perna perna, summer and winter growth rates for infected and non-infected mussels were compared. Likewise effects of parasites on the reproductive output of females were examined.

Finally, possible compensations for disruption of the energy budget by parasites were examined by testing for effects of parasitism on consumption (filtration rate) and respiration.

\section{MATERIALS AND METHODS}

Most of our tests compared the responses of infected and non-infected Perna perna, but infection rates of digenetic trematodes in mussels can only be determined post hoc by dissection of specimens. To reduce the number of mussels needed in the experiments, mussels were collected from populations on the south coast of South Africa where infection rates are high. Mussels from Kowie Point ( $33^{\circ} 38^{\prime} \mathrm{S}, 26^{\circ} 52^{\prime} \mathrm{E}$ ) showed about $50 \%$ infection rates with Proctoeces, and approximately half of the mussels bigger than $70 \mathrm{~mm}$ from Hougham Park $\left(33^{\circ} 47^{\prime} \mathrm{S}, 25^{\circ} 44^{\prime}\right.$ E) were infected with bucephalid sporocysts (Calvo-Ugarteburu \& McQuaid 1998). Because infection was size dependent, different size classes of mussels were sometimes collected from the 2 locations. Mussels infected by each parasite were compared with non-infected individuals from the same site. Mussels seen to be infected with both parasites were discarded, but we have no doubt that in some cases heavy infection with bucephalid sporocysts masked the presence of Proctoeces. In the case of Proctoeces, the number of metacercariae was counted on some occasions, but most experiments only dealt with presence/absence of parasites and did not take different intensities of infection into account. Sporocysts undergo massive asexual reproduction within the host, and quantifying the number of sporocysts was not possible; here again we dealt with only presence/absence of parasites.

When dry weights were required, they were obtained by oven drying at $60^{\circ} \mathrm{C}$ for $48 \mathrm{~h}$.

All data were tested for normality and homogeneity of variances prior to statistical analysis. If they did not fulfil the conditions for parametric tests, the appropriate transformations were done (Zar 1984). If after transformation the conditions were still not fulfilled, non-parametric tests were used as specified.

Condition index. Since several authors have reported a high correlation between condition index and the reproductive state of bivalves (Walne 1970, Gee et al. 1977, Pekkarinen 1991), condition index of infected and non-infected mussels was measured before (January-February) and after (April-May) the major spawning period. Mussels were collected from Kowie Point (length 60-85 mm) and Hougham Park (length 90-110 mm), and their condition was calculated as the ratio of dry weight to shell cavity volume. Total volume of each individual was measured using the water displacement method. Shell volume was measured by the same method, and the shell cavity volume was calculated as the total volume of the specimen minus the volume of the shell. Total length and weight of the mussels were also measured prior to dissection.

The soft tissues were removed, weighed (wet and dry) and examined for parasites.

The condition index was calculated as dry weight in grams divided by the shell cavity volume in millilitres multiplied by 100

The condition indices of mussels with and without Proctoeces and bucephalid sporocysts were compared using $t$-tests. Separate tests were done for samples collected before and after spawning

Gaping, water loss and survival. Mussels between 60 and $90 \mathrm{~mm}$ long were collected from Kowie Point \& Hougham Park. One hundred mussels from each locality were weighed and placed upright in the laboratory, simulating their orientation in the field, with the anterior end down. Relative humidity was kept between 10 and $30 \%$ and temperature between 20 and $30^{\circ} \mathrm{C}$. Observations were made at $2 \mathrm{~h}$ intervals to record gaping. All individuals with valves parted were recorded as gaping, without the width of the gape being taken into account. Mussels were weighed every $6 \mathrm{~h}$ to measure loss of water. Under natural conditions Perna perna is never exposed to air for more than $12 \mathrm{~h}$. Therefore, the number of infected and non-infected mussels that died in the first $12 \mathrm{~h}$ and the amount of water that mussels with and without parasites lost in that period were compared using a Student's $t$-test. For mussels from Kowie Point, a Spearman's correlation test was carried out to check for possible relationships between the number of times the mussels gaped in the first $12 \mathrm{~h}$ and the number of Proctoeces they contained.

In order to check whether the effects of the parasites were more marked under stressful situations, the experiment was continued until the mussels died. The experiment lasted for $84 \mathrm{~h}$, by which time all the mussels had gaped and failed to react to probing and were therefore considered to be dead. The final weight of each mussel was recorded as it was declared dead. Mussels were then dissected and examined for parasites.

For each mussel, the time it took to die, the number of times it gaped and the loss of weight during that time, the presence or absence of Proctoeces and bucephalid sporocysts, the number of Proctoeces 
metacercariae present and the dry weight were recorded.

Total mortality rates and the mean amount of water lost by infected and non-infected mussels were compared using $t$-tests. The relationships between the number of Proctoeces and the number of times the mussels gaped were studied using Spearman's correlation coefficient.

Adductor muscle strength. Mussels from Kowie Point (65-85 mm) and Hougham Park (85-105 mm) were collected in order to test for the effect of parasites on the strength of the adductor muscle.

The force needed to open mussels was measured with an Instron 4301 apparatus. Two small hooks (5-10 $\mathrm{mm}$ long) were inserted into the byssus opening on the anterior ventral surface of the mussels and attached to the jaws of the machine. The machine was run with a uniform speed of separation of the jaws of $100 \pm 20 \mathrm{~mm} \mathrm{~min}^{-1}$ until the mussel stopped offering resistance. The highest force reached during this procedure was recorded. The mussels were then dissected and examined for parasites. The strength of the mussels was recorded as Newtons needed to force them open per gram of dry weight. Samples were compared using a t-test.

Reproduction. Prevalence of Proctoeces is much higher in females that in males (Calvo-Ugarteburu \& McQuaid 1998) and only females were used to study the effects of parasites on reproduction. Four females infected with Proctoeces and 4 non-infected females were dissected. A small portion of the gonad was weighed and placed in Davidson's fixative for histological examination. Five $7 \mu \mathrm{m}$ sections $70 \mu \mathrm{m}$ apart were cut from each gonad and stained with haematoxylineosin to study the reproductive state of the mussel. The number of oocytes present in 3 random microscope fields per section was counted, and 20 oocytes that had been cut through the nucleus were measured in each section using a graduated ocular. The number of oocytes and mean oocyte size in infected and noninfected females were tested using a nested ANOVA (Zar 1984).

In mussels infected with bucephalid sporocysts the gonad is almost obliterated and it is often not possible to determine the sex of the host. Ten animals with parasites, and 10 non-infected females were dissected and processed as above.

Growth. A size range of mussels (20 to $90 \mathrm{~mm}$ ) was collected in October 1992 from Kowie Point ( $\mathrm{n}=1300$ ) and Hougham Park ( $\mathrm{n}=260$ ). The shell of each mussel was clearled and measured and individuals were marked by glueing a small plastic tag to the shell. The mussels were then placed in mesh cages and hung in the sea at approximately $2 \mathrm{~m}$ depth in a mussel farm at Port Elizabeth $\left(33^{\circ} 58^{\prime} \mathrm{S}, 25^{\circ} 38^{\prime}\right.$ E). Mesh size was
$1 \mathrm{~cm}$, which is large enough to ensure a continuous flow of water through the cages and small enough to retain the smaller mussels. In order to check whether the mussels acquired new infections during the experiment, a random subsample ( $\mathrm{n}=10$ to 20 ) was taken every month and rates of infection were checked. The size of each individual was recorded monthly during summer (October 1992 to March 1993). At the end of this period the mussels were dissected and examined for parasites.

Growth rates for infected and non-infected mussels were compared using analysis of covariance, with the initial size of the mussels as a covariate, since growth rates decrease with increasing size (du Plessis 1977. Kautsky 1982, Crawford \& Bower 1983, Cheung 1991). The presence or absence of parasites and, in the case of Proctoeces, host sex were the main effects. Subsequently, mussels were divided into six $10 \mathrm{~mm}$ size classes (Kowie Point: smallest size class $<30 \mathrm{~mm}$, largest class $>70 \mathrm{~mm}_{\text {i }}$ Hougham Park: $<60 \mathrm{~mm}$ to $>100 \mathrm{~mm}$ ) to study size dependent effects of the parasites. The results were analyzed separately for each size class using the Mann-Whitney $U$-test. In order to assess whether the effects of the parasites differed between seasons, the experiment was repeated during winter (May 1993 to November 1993). During the winter experiment, initial sample sizes were 700 for each population. Size dependant effects were examined by dividing samples from each locality into seven $10 \mathrm{~mm}$ size classes (21 to $30 \mathrm{~mm}$... up to $>80 \mathrm{~mm}$ ), with 100 mussels in each size class for each locality. The results were again analyzed using ANCOVA and Mann-Whitney $U$-tests as above.

Filtration and respiration. Perna perna were collected from Kowie Point (60 to $85 \mathrm{~mm}$ length) and Hougham Park (70 to $95 \mathrm{~mm}$ length), The mussels were then transferred to the laboratory, cleaned of fouling organisms and maintained in a re-circulating seawater system at a temperature of 17 to $20^{\circ} \mathrm{C}$ and a salinity of $35 \%$. Mussels were fed twice a day with a suspension of the unicellular alga Dunaliella salina until used in experiments. A flow-through system was used to determine oxygen consumption and filtration rates simultaneously. From a header tank, water was distributed to sixteen $500 \mathrm{ml}$ flasks. Fourteen of the flasks were occupied by 1 mussel each; the remaining two acted as controls and had no mussels. Each flask had an outgoing pipe which siphoned water from the immediate vicinity of the mussel. Outgoing water was collected in a bottom tank, from which it was pumped back to the header tank. Mussels were introduced into the system, with great care taken not to leave any air bubbles which would interfere with the oxygen readings, and left for $1 \mathrm{~h}$ to acclimate before readings were taken. The flow rate through 
each of the flasks was kept between 2 and $20 \mathrm{ml}$ $\min ^{-1}$

Oxygen consumption was measured using an automatic multi-channel respirometer. Each of the outgoing pipes was connected to an oxygen electrode which was calibrated using the 2 control flasks. After allowing a couple of seconds for stabilization, the oxygen concentration from the water in the vicinity of the mussels was measured for $4 \mathrm{~min}$. The difference in oxygen concentration between the control and the experimental flasks was considered to be the oxygen consumed by the mussels. For each mussel, oxygen consumption was noted after 1,3 and $5 \mathrm{~h}$.

Filtration rates were calculated from the difference in algal concentration between the control and experimental flasks. Sinking of algae was insignificant and the decrease in algal concentration was assumed to be due solely to the feeding activity of the mussels. After respiration was measured, $10 \mathrm{ml}$ of water was collected from the outgoing pipe of each flask and diluted with $10 \mathrm{ml}$ of electrolyte, and the number of algal cells was counted using a Coulter counter model ZM with an aperture of $5 \mu \mathrm{m}$.

Filtration and respiration rates were calculated according to the following equations

$$
\begin{gathered}
F=\text { flow rate } \times(1-\text { initial cell concentration/ } \\
\text { final cell concentration }) \\
R=\delta \mathrm{PO}_{2} \times \text { flow rate } \times 12.487
\end{gathered}
$$

where $F$ is filtration rate, $R$ is respiration and $\delta \mathrm{PO}_{2}$ is the partial pressure of oxygen.

After all the measurements were taken the mussels were examined for parasites. Filtration rates and oxygen consumption were normalised to dry weight for each individual, and the data were then tested for normality and homogeneity of variances. Raw filtration rates deviated significantly from the assumption of homoscedasticity and were logarithmically transformed. Filtration rates and oxygen consumption were compared using a 2-way ANOVA, with the presence or absence of parasites and time as the main effects.

\section{RESULTS}

\section{Condition index}

The results of the $t$-tests showed that mussels infected with either parasite had a significantly lower condition index than non-infected mussels, but only in the samples taken after spawning (Table 1, $\mathrm{p}<0.05$ for both parasites). Neither parasite had a significant effect on the condition of the host before spawning (Table 1, p > 0.05 for both parasites).
Table 1 Perna perna. Condition indices of mussels with and

\begin{tabular}{|c|c|c|c|c|}
\hline & \multicolumn{2}{|c|}{ Proctoeces } & \multicolumn{2}{|c|}{ Bucephalid sporocysts } \\
\hline & With & Without & With & Without \\
\hline \multicolumn{5}{|l|}{ Before spawning } \\
\hline Sample size & 37 & 43 & 15 & 22 \\
\hline Mean & 6.19 & 6.09 & 5.11 & 5.67 \\
\hline \multirow[t]{2}{*}{ SD } & 1.12 & 1.13 & 1.00 & 1.22 \\
\hline & \multicolumn{2}{|c|}{$p>0.05$} & \multicolumn{2}{|c|}{$p>0.05$} \\
\hline \multicolumn{5}{|l|}{ After spawning } \\
\hline Sample size & 52 & 22 & 7 & 35 \\
\hline Mean & 4.77 & 5.57 & 5.11 & 6.39 \\
\hline \multirow[t]{2}{*}{ SD } & 1.18 & 1.35 & 1.43 & 1.53 \\
\hline & \multicolumn{2}{|c|}{$\mathrm{p}<0.05$} & \multicolumn{2}{|c|}{$p<0.05$} \\
\hline
\end{tabular}
without parasites (Proctoeces and bucephalid sporocysts) before and after spawning. $p$-values significant at $p<0.05$

Table 2. Perna perna. Amount of water lost ( $\mathrm{g}$ water $\mathrm{g}^{-1} \mathrm{dry}$ wt) by mussels with and without parasites after $12 \mathrm{~h}$ and at the end (after $84 \mathrm{~h}$ ) of the gaping experiment. p-values significant at $\mathrm{p}<0.05$

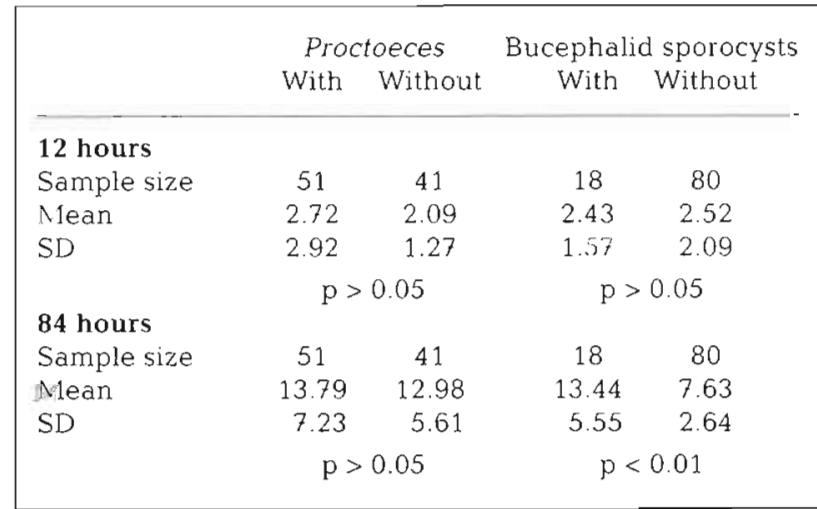

\section{Gaping, water loss and survival}

The variances of the amount of water lost by mussels from Kowie Point after $12 \mathrm{~h}$ were not homogeneous, even after logarithmic transformation, therefore Mann-Whitney $U$-tests were used to compare water loss by infected and non-infected specimens. The results showed no significant differences for either parasite after $12 \mathrm{~h}(\mathrm{p}>0.05)$ nor for Proctoeces by the end of the experiment (Table 2). However, mussels infected with bucephalid sporocysts lost significantly more water than non-infected individuals by the time the experiment ended ( $\mathrm{p}<0.01$; Table 2).

Spearman's correlation test for data on all mussels showed a significant positive correlation between the amount of water lost during the first $12 \mathrm{~h}$ and the number of times that the mussels gaped (Table $3, p<0.01$ ). However, there was no significant relationship between the presence or number of parasites and either the amount of water lost or the number of times the 
mussels gaped during the first $12 \mathrm{~h}$ (Table 3 ). This situation had changed by the end of the experiment, at which stage there was no significant relationship between the water lost and the gaping behaviour of the mussels (Table 3). At the end of the experiment, again, there was no significant correlation between the number of Proctoeces and either the amoun.t of water lost by the mussels or the number of times they gaped (Table 3 ). However, the presence of bucephalid sporocysts was associated with a significant increase in the amount of water lost by the mussels (Table 3 ).

Fig. 1 represents the survival of mussels with and without parasites when exposed to air. No mussels died during the first $12 \mathrm{~h}$. The t-tests comparing the mean time that infected and noninfected mussels took to die showed no significant differences for either Proctoeces or bucephalid sporocysts ( $\mathrm{p}=0.68$ and $\mathrm{p}=0.23$ respectively).
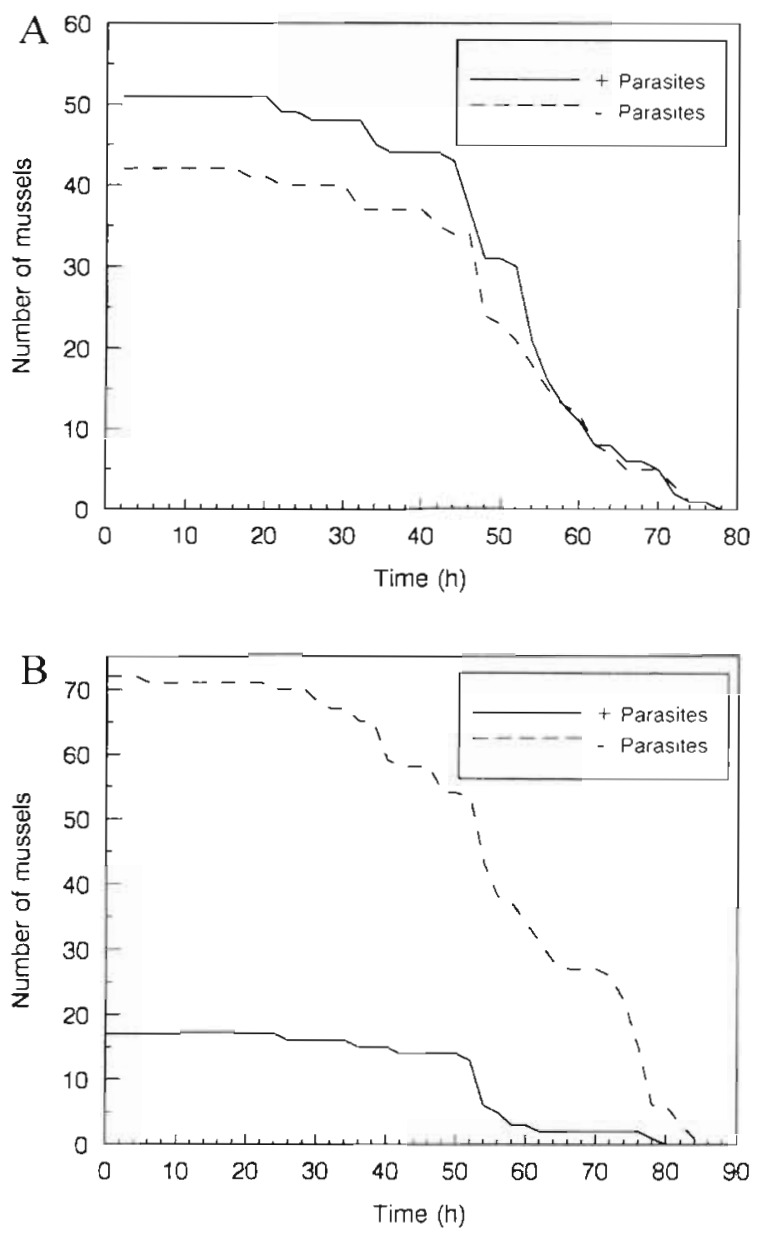

Fig. 1. Perna perna. Survival of mussels with $(+)$ and without (-) Proctoeces (A) or bucephalid sporocysts (B) when exposed to air
Table 3. Perna perna. Values of $r$ generated by Spearman's correlation tests on the relationships among parasitism, frequency of gaping and water loss of mussels after $12 \mathrm{~h}$ and at the end (after $84 \mathrm{~h}$ ) of the gaping experiment. $p$-values significant at $p<0.05$

\begin{tabular}{|lcccc|}
\hline & \multicolumn{2}{c}{12 hours } & \multicolumn{2}{c|}{84 hours } \\
& Gaping & Water lost & Gaping & Water lost \\
\hline Proctoeces & & & & \\
Presence & 0.19 & 0.08 & 0.15 & 0.01 \\
& $(p>0.05)$ & $(p>0.05)$ & $(p>0.05)$ & $(p>0.05)$ \\
Number & 0.14 & 0.07 & 0.13 & 0.01 \\
& $(p=0.05)$ & $(p>0.05)$ & $(p>0.05)$ & $(p>0.05)$ \\
Water lost & 0.34 & & 0.04 & \\
(all mussels $)$ & $(p<0.01)$ & & $(p>0.05)$ & \\
Bucephalid sporocysts & 0.04 & 0.001 & 0.15 & 0.48 \\
Presence & $(p>0.05)$ & $(p>0.05)$ & $(p>0.05)$ & $(p<0.01)$ \\
Water lost & 0.34 & & 0.15 & \\
(all mussels $)$ & $(p<0.01)$ & & $(p>0.05)$ & \\
\hline
\end{tabular}

\section{Adductor muscle strength}

To allow for differences in size, the force required to open mussels was standardized to dry body weight. In the case of mussels infected with Proctoeces, the variances were not homogeneous; therefore, the data were logarithmically transformed and compared using a $t$ test. There was no significant difference in the force required to open Proctoeces-infected and parasite-free mussels (Table 4, p > 0.05). In the case of the sporocysts, a significantly greater force was needed to open non-infected mussels than infected ones $(p<0.05)$. More force was needed to open mussels from Kowie Point than mussels from Hougham Park, even though they were smaller.

Table 4. Perna perna. Newtons per gram dry body weight needed to force open infected and non-infected mussels. $\mathrm{p}$-values significant at $\mathrm{p}<0.05$

\begin{tabular}{|c|c|c|c|c|}
\hline & \multicolumn{2}{|c|}{ Proctoeces } & \multicolumn{2}{|c|}{ Bucephalid sporocysts } \\
\hline & With & Without & With & Without \\
\hline Sample size & 41 & 21 & 18 & 47 \\
\hline Mean & 85.84 & 76.29 & 51.43 & 59.70 \\
\hline \multirow[t]{2}{*}{$\mathrm{SD}$} & 22.38 & 14.16 & 14.81 & 13.40 \\
\hline & \multicolumn{2}{|c|}{$p>0.05$} & \multicolumn{2}{|c|}{$\mathrm{p}<0.05$} \\
\hline
\end{tabular}

\section{Reproduction}

Histologically and morphologically, the ovaries of mussels infected with Proctoeces are identical to those of non-infected individuals. The nested ANOVA com- 
paring the number of oocytes in infected and noninfected females showed no significant differences in oocyte number owing to Proctoeces $15 \%$ of the variation); most of the variation observed $(84 \%)$ was due to the microscope field examined.

Likewise, nested ANOVA indicated that mean oocyte diameter did not vary significantly between individual mussels $(0.3 \%$ of the variation), nor was it affected by the presence of Proctoeces $(1.3 \%)$. Histological examination of individuals infected with bucephalid sporocysts revealed that all of them were completely castrated, with no trace of sex products left, so that it was not possible to count or measure oocytes.

\section{Growth}

Data on infection rates in the subsamples of 10 to 20 mussels taken every month showed that infection rates stayed constant during the whole experiment (Chisquared test, $\mathrm{p}>0.05$ ).
Growth rates of mussels with and without Proctoeces or bucephalid sporocysts are shown separately for summer and winter months in Fig. 2. Analysis of covariance using initial size as a co-variate showed that sex had no significant effect on growth. However, mussels infected with Proctoeces grew significantly less than non-infected mussels both in summer and in winter (Table 5).

Mann-Whitney $U$-tests comparing growth rates of mussels with and without parasites in each of the 6 size classes showed that Proctoeces had a detrimental effect on the growth of only the smallest individuals ( $p<0.05$ for mussels $<30 \mathrm{~mm}$ during both summer and winter). Although infected mussels grew less than noninfected individuals in most of the other size classes, the differences were not statistically significant $(p>$ 0.05 for all size classes $>30 \mathrm{~mm}$; Fig. 3 ).

In the case of mussels infected with bucephalid sporocysts, it was not possible to determine the sex of infected animals in most cases, therefore the ANCOVA used only parasitism as a main effect. The presence of parasites had no significant effect on the
Fig. 2. Perna perna. Growth rates of mussels with $(+)$ and without (-) Proctoeces (A, B) or bucephalid sporocysts (C, D) in summer and winter. Means $\pm \mathrm{SD}$
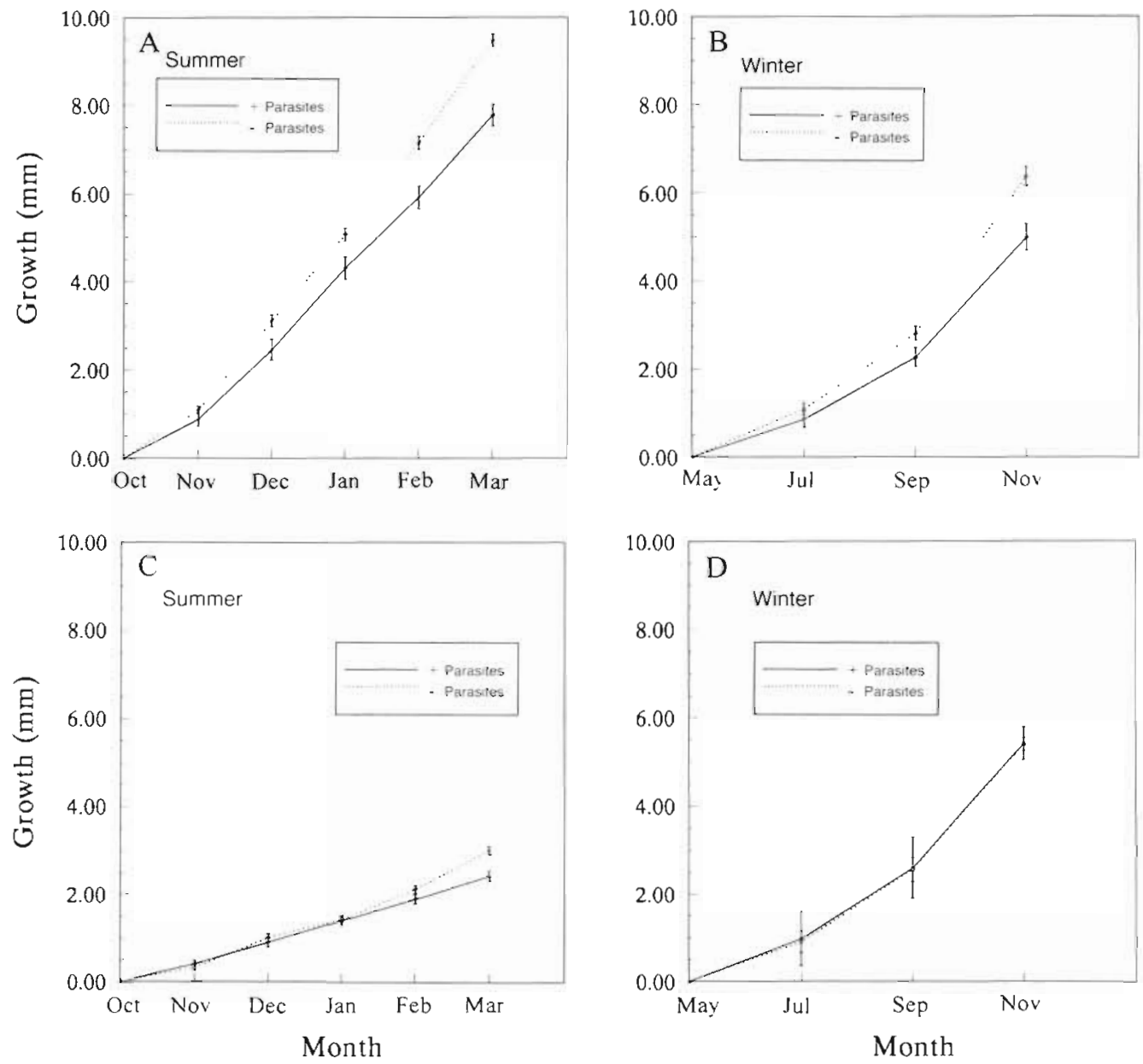


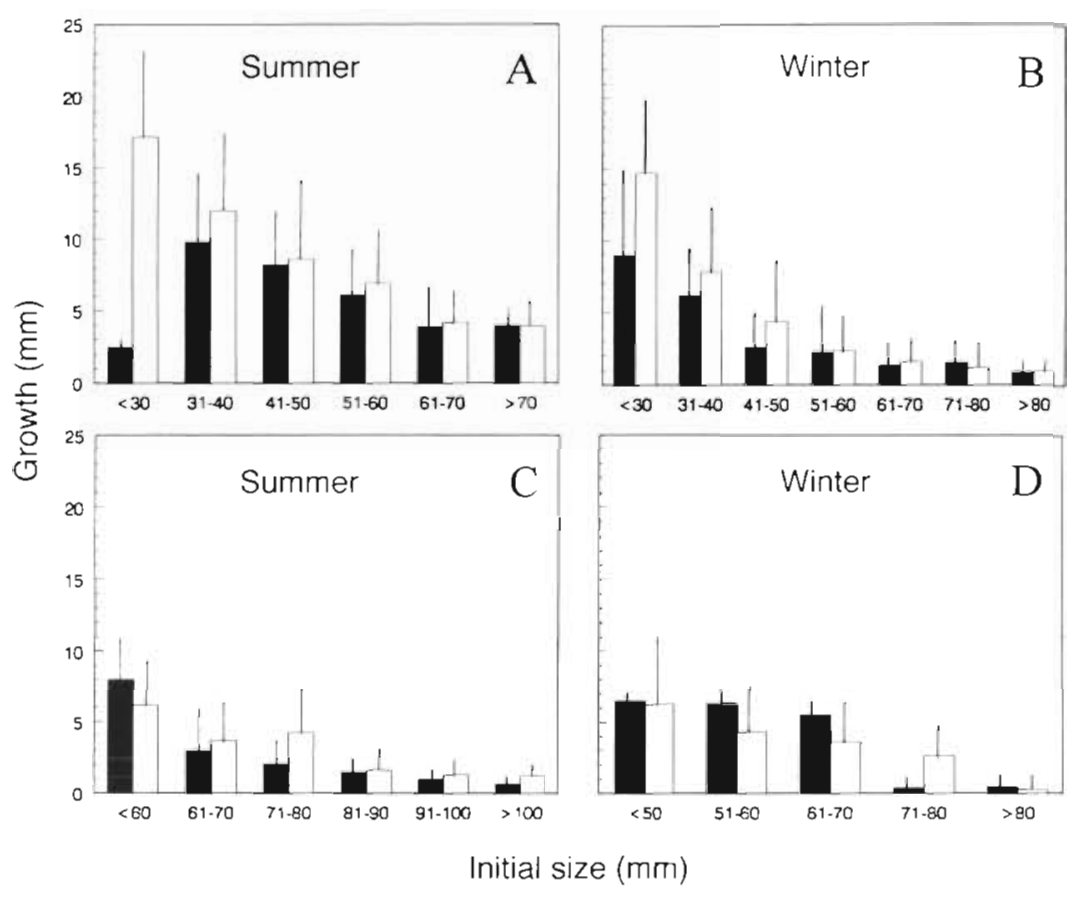

Fig. 3. Perna perna. Growth rates of different size classes of mussels with (solid bars) and without (open bars) Proctoeces (A, B) or bucephalid sporocysts (C, D) during summer and winter. Means $+\mathrm{SD}$ als of the same size $(p<0.05$ both in summer and in winter, Fig. 3)

\section{Filtration and respiration}

Fig. 4 shows filtration rates $\left(\mathrm{l} \mathrm{h}^{-1} \mathrm{~g}^{-1}\right.$ dry wt) of Perna perna with and without metacercariae of Proctoeces and bucephalid sporocysts. Neither Proctoeces nor the sporocysts had a significant effect on the filtration rates of the mussels ( $p=0.5$ and 0.9 respectively). In both cases filtration was highly dependent on time $(\mathrm{p}<0.01$ for both parasites), with lower filtration rates as time increased.

A 2-way ANOVA showed that respiration was not significantly influenced by either time ( $p>0.05$ for both parasites) or the presence of parasites ( $p=$ 0.09 for Proctoeces and $p=0.41$ for bucephalid sporocysts) (Fig. 5). There were no significant interactions between. the effects of the parasite and time for either parasite.

\section{DISCUSSION}

(Table 6). However, the Mann-Whitney $U$-tests showed that mussels of 71 to $80 \mathrm{~mm}$ with sporocysts did grow significantly less than non-infected individu-

Table 5. Results of analysis of covariance (using initial size as a covariate) comparing growth rates of Perna perna with and without Proctoeces during summer and winter months. $p$-values significant at $p<0.05$

\begin{tabular}{|rrrcc|}
\hline $\begin{array}{l}\text { Source of } \\
\text { variation }\end{array}$ & $\mathrm{S}$ & $\mathrm{df}$ & F-ratio & $\mathrm{p}$ \\
\hline $\begin{array}{l}\text { SUMMER } \\
\text { Covariate: }\end{array}$ & & & & \\
$\quad$ Size & 4320.66 & 1 & 180.01 & $<0.01$ \\
Effects: & & & & \\
$\quad$ Sex & 45.36 & 1 & 1.89 & $>0.05$ \\
$\quad$ Parasite & 124.66 & 1 & 5.19 & $<0.05$ \\
Interactions & 30.23 & 1 & 1.26 & $>0.05$ \\
Residual & 10681.28 & 4.45 & & \\
WINTER & & & & \\
Covariate: & & & & \\
$\quad$ Size & 4071.87 & 1 & 219.36 & $<0.01$ \\
Effects: & & & & \\
$\quad$ Sex & 4.37 & 1 & 0.23 & $>0.05$ \\
$\quad$ Parasite & 76.93 & 1 & 4.14 & $<0.05$ \\
Interactions & 128.15 & 1 & 6.90 & $<0.01$ \\
Residual & 6719.52 & 362 & & \\
\hline
\end{tabular}

The first set of tests examined the effects of the 2 parasites on the general health and survival of Perna perna. Condition indices are considered to be good indicators of the health status of bivalves, although they may be affected by many factors. Fluctuations of

Table 6. Results of the analysis of covariance (using the initial size as a covariate) comparing growth rates of Perna perna with and without bucephalid sporocysts during sum. mer and winter months. p-values significant at $p<0.05$

\begin{tabular}{|c|c|c|c|c|}
\hline $\begin{array}{l}\text { Source of } \\
\text { variation }\end{array}$ & S & df & $F$-ratio & $\mathrm{p}$ \\
\hline \multicolumn{5}{|l|}{ SUMMER } \\
\hline \multicolumn{5}{|l|}{ Covariate. } \\
\hline Size & 326.67 & 1 & 75.17 & $<0.01$ \\
\hline \multicolumn{5}{|l|}{ Effects: } \\
\hline Parasite & 12.02 & 1 & 2.77 & $>0.05$ \\
\hline Residual & 604.01 & 139 & & \\
\hline \multicolumn{5}{|l|}{ WINTER } \\
\hline \multicolumn{5}{|l|}{ Covariate: } \\
\hline Size & 5659.82 & 1 & 301.08 & $<0.01$ \\
\hline \multicolumn{5}{|l|}{ Effects: } \\
\hline Parasite & 0.02 & 1. & 0.001 & $>0.05$ \\
\hline Residual & 6109.56 & 325 & & \\
\hline
\end{tabular}



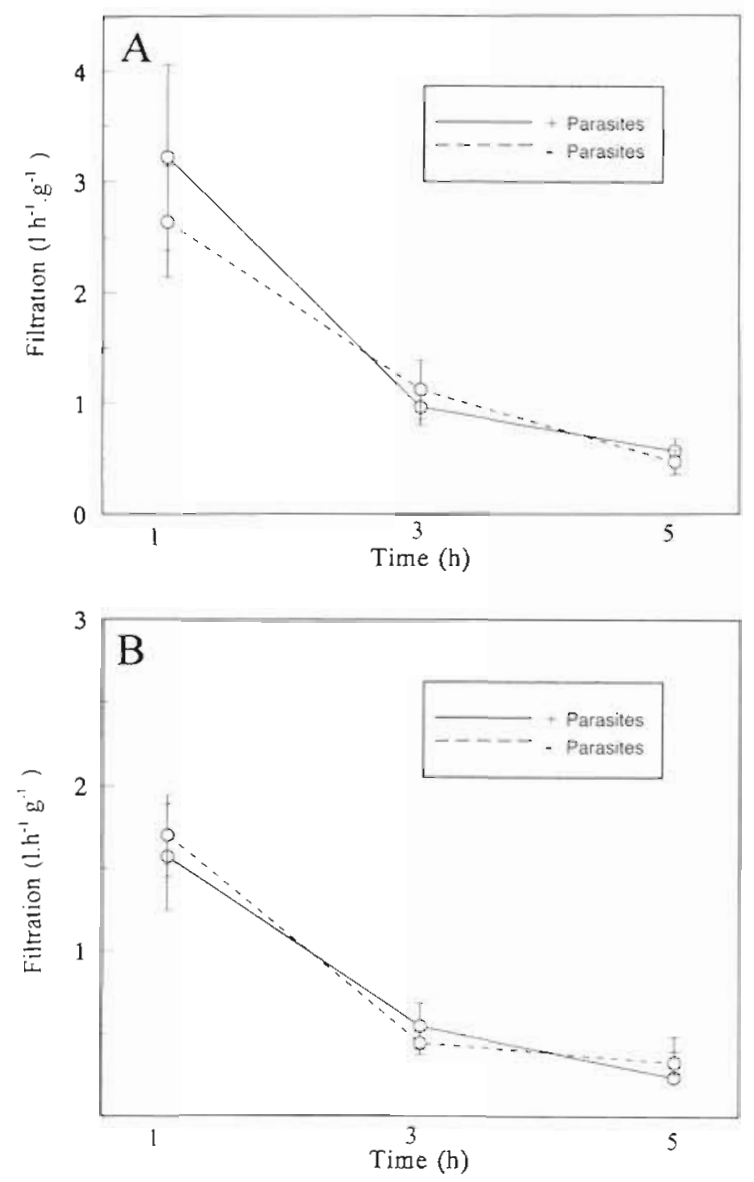

Fig. 4. Perna perna. Filtration rates of mussels with $(+)$ and without $(-)$ Proctoeces (A) or bucephalid sporocysts (B). Means $\pm \mathrm{SD}$

condition have been reported to result from environmental stressors, such as thermal stress and starvation (Cee et al. 1977) and exposure to parasites (Kent 1979, Pregenzer 1981. Theisen 1987, Gauthier et al. 1990). Several authors have noticed seasonal changes in the condition of bivalve molluscs, and have related them to the gametogenic cycle (Baird 1966. Walne 1970, Gee et al. 1977, Kent 1979, Pekkarinen 1991).

Previous studies on the effects of bucephalids on the condition of the host have shown contradictory results. Whilst Gauthier et al. (1990) found that oysters infected with Bucephalus tend to have low values of condition index, Pekkarinen (1993) concluded that unionid mussels infected with bucephalid sporocysts did not always have a lower condition than non-infected individuals. This could be the result of seasonal differences in the timing of the 2 studies. It could also be due to experimental error. Since the bucephalid sporocysts infiltrate the gonad of the host, eventually replacing it, distinction between gonad tissue and parasite tissue is not always possible. Thus this method is not very accu- rate for this parasite and the results are not always completely reliable.

The results of our study show that there was no apparent effect of either Proctoeces or bucephalid sporocysts on the condition index of Perna perna before spawning, but that both parasites had a negative effect on condition after spawning (Table 1). This would agree with the results of those authors who have found a deleterious effect of parasites only under stressful situations (Hepper 1955, Bayne et al. 1978). Spawning can be considered a natural stressor since it can cause a reduction in filtration rate and postspawning individuals are frequently depleted of energy reserves (Newell \& Barber 1988). Our results also raise the question of why the bucephalid sporocysts have a negative effect on condition after spawning if they castrate the host. A possible answer may be related to the degree of infection and castration, since only the presence/absence of sporocysts was considered and not the intensity of infection.
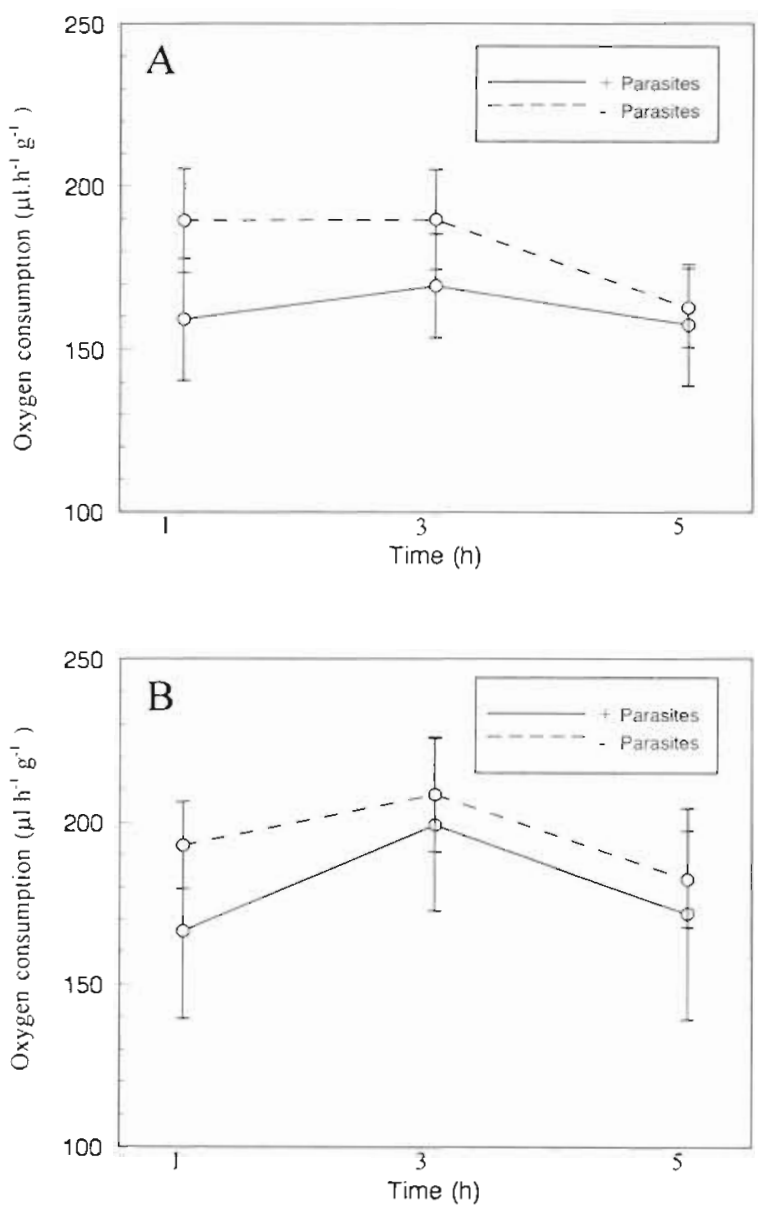

Fig. 5. Perna perna. Oxygen consumption of mussels with $(+)$ and without (-) Proctoeces (A) or bucephalid sporocysts (B). Means $\pm S D$ 
Even if parasites affect the host only when it is already under some sort of environmental stress, the importance of these effects must not be underestimated. As Zuk (1987) pointed out, parasites which exert detrimental effects only when environmental conditions are stressful. may have a profound effect on host biology.

With respect to mortality, even when exposed to air for abnormally long periods, there were no significant differences in the time that infected and non-infected mussels took to die. Indeed, not one mussel died in the first $12 \mathrm{~h}$ of the gaping experiment (Fig. 1), which is longer than they would be exposed to air in the field. However, while parasites did not affect mortality in relation to air exposure, there was an effect on water loss.

Mussels are facultative anaerobes, and when exposed to air they have 2 alternatives: they may close their valves and switch to anaerobic metabolism, minimizing the risk of desiccation, but using energy reserves less efficiently, or they may carry on with aerobic metabolism. Marshall \& McQuaid (1993) suggested that Perna perna relies on aerobıc metabolism during air exposure, which implies a certain degree of shell gaping. Under natural conditions, mussels do not gape all the time, but open and close the valves according to their oxygen demands, losing some water every time they gape. The results of this experiment showed that there was a correlation between the number of times the mussels gaped and the amount of water they lost during the first $12 \mathrm{~h}$ (Table 3).

By the end of the experiment there was no significant relationship between water loss and the number of times that the mussels gaped. In the case of individuals from Kowie Point (non-infected and those infected with Proctoeces), the amount of water lost at the end of the experiment was not related to the time that the mussels spent out of water either. Nor did the presence of Proctoeces affect water loss. Mussels from Hougham Park showed different behaviour. For them, there was again no significant relationship between the amount of water that the mussels lost and the number of times they gaped, but the longer the mussels were exposed to air the more water they lost. Also, specimens infected with bucephalid sporocysts lost significantly more water than non-infected specimens (Table 2). This increase in water loss was not the result of parasite-induced abnormal gaping behaviour as there was no relationship between presence of parasites and the number of times the mussels gaped. An alternative explanation is that the mussels, when not gaping, did not seal the valves properly and continuous evaporation of water took place. This conforms with the observed weakening of the adductor muscle by bucephalid sporocysts (Table 4 ).
Weakening of infected hosts has been noticed before (Howell 1967, Canzonier 1972) and, apart from the effect on the amount of water lost, it has obvious ecological implications by rendering the host more susceptible to certain predators. This debilitation of the mussels would not affect predation by all predators. For example, octopuses which fail to pull a mussel open instead drill a hole in it, inject saliva, which paralyses the adductor muscles, and then pull it open (McQuaid 1994); in this case the strength of the mussel affects how it is killed, not whether it is killed. But weakening of the adductor muscles may facilitate predation by other animals such as starfish. Norberg \& Tedengren (1995) measured the force applied by Asteria rubens trying to open mussels and found that the starfish applied a maximum force between 7.6 and 70 Newtons (cf. Table 5). Jonsson \& Andre (1992) noticed that cockles Cerastoderma edule heavily infected with Cercaria cerastodermae were slow to close their valves and on several occasions they found the whelk Nassarius reticulatus attacking gaping cockles that were not yet dead. Similarly, Howell (1967) observed shrimps probing between the valves of gaping oysters which were heavily infected with Bucephalus longicornutus. Although bucephalid sporocysts do not directly affect mortality of the mussels, it is possible that, through the weakening of the adductor muscle, this parasite may make Perna perna more susceptible to some predators.

The second aspect we considered was the effect of parasites on the competitive abilities of Perna perna. One of the main effects of trematode infection in molIuscs is parasitic castration. This may lead to an increase in growth rate and/or gigantism as energy formerly allocated by the host to reproduction is put into somatic growth (e.g. Wright 1971, Wilson \& Denison 1980, Sluiters 1981). However, the effect on growth rate may depend on the timing of infection. If destruction of the gonad occurs before the host is reproductively active it will not free energy since the host was not using energy for reproduction. In this case, if there is any effect on growth it will be a reduction, since not only is no energy re-routed from reproduction, but the host also has to deal with damage caused by the parasite (Sousa 1983).

Our results indicate that there is no fixed relationship between the effects of parasites on growth and reproduction; the effect depends on the parasite-host system studied. In our case, 2 parasites affected different components of the host energy budget. Proctoeces affected growth but not reproduction, and bucephalid sporocysts affected reproduction but (except for the largest mussels) not growth.

These results are in agreement with most of the literature referring to these 2 parasites. In general most infections by bucephalid sporocysts and cercariae in 
bivalve molluscs have been reported to start in the gonad, with the sporocysts eventually replacing all the gonadal tissue and spreading onto other organs (see Howell 1967 and Lauckner 1983 for references). One exception was found by Cheng \& Burton (1965), who noted that Bucephalus sp. infests mainly the digestive gland of the oyster Crassostrea virginica (Gmelin).

The fact that the bucephalid sporocysts castrate Perna perna will have an obvious effect on the mussel population, especially in places with a high prevalence of this parasite. We must also take into account the fact that the prevalence of this parasite increases with the size of the individual, with mussels bigger than $70 \mathrm{~mm}$ having up to $70 \%$ infection rates in some locations (Calvo-Ugarteburu \& McQuaid 1998). Partitioning of energy in mussels varies with size, with small mussels spending more energy on growth and large mussels putting most energy (sometimes over $90 \%$ ) into reproduction (reviewed by Seed \& Suchanek 1992). The effect on growth is less important, as bucephalid sporocysts decrease growth of only large mussels (71 to $80 \mathrm{~mm}$ ). These individuals channel most of their energy into reproduction and exhibit low growth rates anyway.

Lasiak (1989) found prevalences of Proctoeces metacercariae in Perna perna at several places along the South African coast similar to ours. She concluded that, being an active growth phase in the life-cycle, the metacercariae probably ingest material from the host's tissues, disturbing its growth and reproduction. This study shows that Proctoeces has a harmful effect on the growth of the mussels, especially of those smaller mussels which, under normal conditions, would expend most of their energy on growth (see Seed \& Suchanek 1992 for references). Within a mussel bed, mussels compete for space and food, with slower-growing mussels having a competitive disadvantage (Kautsky 1982). Therefore, any depression of growth rate is likely to reduce the competitive ability of the mussels. Furthermore, although Proctoeces has no direct effect on mussel reproduction, it may have an indirect effect by reducing growth rates, since fecundity is size related and smaller mussels spend less energy on reproduction than larger ones (Seed \& Suchanek 1992).

Mytilids are widely reported to have different seasonal growth rates (Andreu 1965, Dare \& Edwards 1976, du Plessis 1977, Berry 1978, Crawford \& Bower 1983, Rodhouse et al. 1984, Page \& Hubbard 1987, Anwar et al. 1990, Richardson et al. 1990, Cheung 1991, 1993, Sukhotin \& Kulakowski 1992, van Erkom Schurink \& Griffiths 1993). We did not set out to study seasonal growth rates, and the faster growth in winter at Hougham Park was probably due to the larger initial size of the mussels used in the summer trial. In both cases the effects of the parasites were consistent between seasons; the bucephalid sporocysts had no significant effect on growth in either summer or winter whilst Proctoeces significantly depressed growth of mussels both in summer and in winter, even though the Mann-Whitney $U$-test showed that it only affected the smallest individuals ( 21 to $30 \mathrm{~mm}$; Fig. 3). This presumably reflects the fact that small mussels put more energy into growth.

Finally we considered possible re-allocation or compensation within the energy budget. Many studies have been done on the physiological responses of mussels to different environmental conditions (e.g. Winter 1973, Andreu 1976, Bayne et al. 1978, Cabanas et al. 1979, Kiorboe et al. 1980, Navarro \& Winter 1982 , Hawkins et al. 1985, Meyhofer 1985, Clarke \& Griffiths 1990, Grant \& Thorpe 1991, Navarro et al. 1991, van Erkom Schurink \& Griffiths 1992, Widdows \& Page 1993). Most of these works found filtration rates between 0.1 and $5.31 \mathrm{~h}^{-1}$, depending on the size of the mussel and the conditions of temperature, particle concentration and flow rate (Winter 1973, Andreu 1976 , Cabanas et al. 1979, Kiorboe et al. 1980, Meyhofer 1985, Clarke \& Griffiths 1990, Ndvarro et al. 1991, van Erkom Schurink \& Griffiths 1992, Widdows \& Page 1993). Filtration rates found in this study were very low (Fig 4), possibly because of low flow rates (Walne 1972), but within the range of values previously reported.

In comparison, very little is known about the effects of parasites on molluscan host physiological processes, and results from different studies are often contradictory. Ishak et al. (1970) found that schistosome-infected Biomphalaria alexandrina showed a consistently lower rate of oxygen consumption than uninfected individuals, whilst Meakins (1980) concluded that larval Schistosoma mansoni elevated the oxygen consumption of Biomphalaria glabrata. Several authors have used changes in filtration or respiration to explain changes in other parameters of the energy budget. For example, Wesenberg-Lund (1934) explained gigantism as a result of an increase in the amount of food eaten, and Williams \& Gilbertson (1983) found that B. glabrata infected with $S$. mansoni for $33 \mathrm{~d}$ fed more often than uninfected snails. On the other hand, this has been contradicted in several studies. For example, Meuleman (1972) found that infected snails consumed less food than controls from the third week after infection onwards.

With respect to bivalves, the effects of parasites seem to be more uniform. Bayne et al. (1978) found lowered filtration rates in Mytilus edulis infected with Mytilicola intestinalis, although only under extreme conditions of temperature and/or food availability. Ward \& Langdon (1986) demonstrated that parasitism by natu- 
rally occurring densities of Boonea impressa deleteriously affects the oyster Crassostrea virginica by significantly reducing filtration rates, and Bierbaum \& Shumway (1988) found lower respiration and filtration rates in Mytilus edulis infected with Pinnotheres maculatus than in non-infected individuals, though they failed to find any differences in assimilation efficiency.

The results from this study show that neither infection with Proctoeces nor infection with bucephalid sporocysts had a significant effect on filtration rates or oxygen consumption of Perna perna, even though the parasites affected either reproduction or growth. Thus there was no compensation for the energy lost within the production fraction (growth and reproduction) of the energy budget via either decreased respiration or increased consumption. The fact that the effects of the parasites are directed at the fraction of the energy budget allocated to production rather than maintenance could be considered a parasitic adaptation. Host survival is necessary for parasite survival, therefore the parasite should influence the metabolism of the host as little as possible (Davis \& Farley 1973, Jokela et al. 1993, J. Taskinen pers. comm.).

Even though there is no apparent direct effect of either Proctoeces or the bucephalid sporocysts on survival of their host, infection seems to be associated with a substantial reduction in fitness. The 2 parasites studied affect the host in different but complementary ways. The effects of both parasites are concentrated on those size classes of mussel which channel most energy into the portion of the energy budget affected by the parasite. Proctoeces affects growth only in the smaller individuals, which normally put most energy into growth; and the bucephalid sporocysts castrate the larger mussels, which expend most energy on reproduction. By reducing growth rates of small mussels or castrating large mussels, these parasites effectively remove them from the breeding population and reduce their competitive abilities. These effects on growth and reproduction are 2 of the mechanisms by which parasites may influence interactions between competing hosts species. Perna perna does not show any compensation for these negative effects. The energy lost for growth or reproduction is not replaced by an increase in filtration or compensated for by a reduction in respiration, rather it is simply lost to the parasite.

In this study we have seen how parasites affect the indigenous mussel Perna perna and hence are likely to affect its interactions with the invasive Mytilus galloprovincialis. Since for a parasite community the resource base is the host population, this situation raises the question of the fate of the parasite community if $P$. perna is competitively displaced by $M$. galloprovincialis. Will the parasites in turn also become extinct or will they develop in $M$. galloprovincialis?
Survival of the parasite implies new adaptations for infecting new hosts. Combes (1991) outlined 3 possible outcomes for a case like this: (1) The parasite may develop in the new host incidentally, without dynamic or genetic consequences for the parasite. (2) The parasite may develop in both hosts, which means an increase in host spectrum with possible dynamic consequences for the parasite. (3) The parasite may develop in the new host, but its lineage may diverge genetically and undergo speciation.

In conclusion, the absence of digenetic trematodes in Mytilus galloprovincialis, together with their high prevalences and negative effects on Perna perna, may help to explain the success of $M$. galloprovincialis in South Africa. Not only is $M$. galloprovincialis competitively superior to $P$. perna, but it is also free of parasites. It remains to be seen whether either parasite will develop in $M$. galloprovincialis, in which case this mussel may lose some of its competitive advantage; or whether $M$. galloprovincialis will drive both $P$. perna and its parasites to extinction.

Acknowledgements. We thank Atlas Sea Farm for the use of their facilities to grow mussels and A. Dye and Z. Nomandela from the Zoology Department of UNITRA for the use of their equipment and all their help in measuring respiration and filtration rates. We are grateful to the Joint Research Committee of Rhodes University for their financial support.

\section{LITERATURE CITED}

Anderson RM (1978) The regulation of host population growth by parasite species. Parasitology 76:119-157

Anderson RM, Crombie J (1984) Experimental studies of ageprevalence for Schistosoma mansoni infections in populations of Biomphalaria glabrata. Parasitology 89:79-104

Anderson RM. May RM (1978) Regulation and stability of host-parasite population interactions. 1. Regulatory processes. J Anim Ecol 47:219-247

Andreu B (1965) Biologia y parasitologia del mejillon gallego Ciencias 30:107-118

Andreu B (1976) El cultivo de mejillon en Europa II Aspectos biologicos y ecologicos; enemigos y parasitos. Anais Acad Bras Ciencias 47(Suppl):23-36

Anwar NA, Richardson CA, Seed R (1990) Age determination, growth rate and population structure of the horse mussels Modiolus modiolus. J Mar Biol Assoc UK 70:441-457

Baird RH (1966) Factors affecting the growth and condition of mussels (Mytilus edulis). Fish Invest Mar Fish GB Ser II Minist Agric Fish Food 25:1-33

Barnard CJ, Behnke JM (1990) Parasitism and host behaviour 1st edn. Taylor and Francis Ltd, London

Bayne BL, Holland DL, Moore MN, Lowe DM, Widdows J (1978) Further studies on the effects of stress in the adult on the eggs of Mytilus edulis. J Mar Biol Assoc UK 58: $825-841$

Berry PF (1978) Reproduction, growth and production in the mussel Perna perna $L$. on the east coast of South Africa. Oceanogr Res Inst S Afr Invest Rep 48:1-28

Bierbaum RM, Shumway SE (1988) Filtratıon and oxygen con- 
sumption in mussels, Mytilus edulis, with and without pea crabs, Pinnotheres maculatus. Estuaries 11:264-271

Blower S, Roughgarden J (1987) Population dynamics and parasite castration: a mathematical model. Am Nat 129 $730-754$

Breytenbach GJ (1986) Impacts of alien organisms on terrestrial communities with emphasis on communities of the south-western Cape. In: Macdonald IAW, Kruger FJ, Ferrar AA (eds) The ecology and management of biological invasions in southern Africa, 1st edn. Oxford University Press, Cape Town, p 229-238

Bruton MN (1986) The life history styles of invasive fishes in southern Africa. In: Macdonald IAW, Kruger FJ, Ferrar AA (eds) The ecology and management of biological invasions in southern Africa, 1st edn. Oxford University Press, Cape Town, p 201-208

Bruton MN, van As JG (1986) Faunal invasions of aquatic systems in southern Africa, with suggestions for their management. In: Macdonald IAW, Kruger FJ, Ferrar AA (eds) The ecology and management of biological invasions in southern Africa, 1st edn. Oxford University Press, Cape Town, $\mathrm{p} 47-62$

Cabanas JM, Gonzalez JJ, Marino J, Perez A, Roman G (1979) Estudio del mejillon y de su epifauna en los cultivos flotantes de la Ria de Arosa. 1lI. Observaciones previas sobre la retencion de particulas y la biodeposicion de una batea. Bol Inst Espa Oceano V(268):44-50

Calvo-Ugarteburu G, McQuaid CD (1998) Parasitism and introduced species: epidemiology of trematodes in the intertidal Perna perna and Mytilus galloprovincialis. J Exp Mar Biol Ecol 220:47-65

Canzonier WJ (1972) Cercaria tenuans, larvae trematode parasite of Mytilus and its significance in mussel culture. Aquaculture 1:267-278

Cheng TC (1967) Marine molluscs as hosts for symbiosis with a review of known parasites of commercially important species. Adv Mar Biol 5:1-300

Cheng TC, Burton RW (1965) Relationships between Bucephalus sp. and Crassostrea virginica: histopathology and sites of infection. Chesapeake Sci 6:3-16

Cheung SG (1991) Energetics of transplanted populations of the green-lipped mussel Perna viridis L. (Bivalvia: Mytilacea) in Hong Kong. II. Integrated energetic budget. Asian Mar Biol 8:133-147

Cheung SG (1993) Population dynamics and energy budgets of green-lipped mussel, Perna viridis L., in a polluted harbour. J Exp Mar Biol Ecol 168:1-24

Clarke BC, Griffiths CL (1990) Ecological energetics of mussels Choromytilus meridionalis under simulated intertidal rock pool conditions. J Exp Mar Biol Ecol 137:63-77

Combes C (1991) Evolution of parasite life cycles. In: Toft CA, Aeschlimann A, Bolis L (eds) Parasite-host associations. Coexistence or conflict? Oxford University Press, Oxford. p $62-82$

Crawford RJM, Bower DF (1983) Aspects of growth, recruitment and conservation of the brown mussels Perna perna along the Tsitsikama coast. Koedoe 26:123-133

Dare PJ, Edwards DB (1976) Experiments on the survival, growth and yield of relaid seed mussels (Mytilus edulis) in the Menai Strait, North Wales. J Cons Cons Int Explor Mer 37:16-28

Davis DS, Farley J (1973) The effects of parasitism by the trematode Cryptocotyle lingua (Creplin) on digestive efficiency in the snail host, Littorina saxatilis (Olivi). Parasitology 66:191-197

Drake JA, Mooney HA, di Castri F, Groves RH, Kruger FJ, Rejmanek M, Williamson M (eds) (1989) Biological inva- sions: a global perspective. SCOPE 37 John Wiley and Sons, Chichester

du Plessis AJ (1977) Larval development, settlement and growth of the black mussel Choromytilus meridionalis in the Saldanha Bay region. Trans R Soc S Afr 42:303-316

Ehrlich PR (1989) Attributes of invaders and the invading processes: vertebrates. In: Drake JA, Mooney HA, di Castri F, Groves RH, Kruger FJ, Rejmanek M. Williamson M (eds) Biological invasions: a global perspective. SCOPE 37. John Wiley and Sons, Chichester, p 315-328

Gauthier JD, Soniat TM, Rogers JS (1990) A parasitological survey of oysters along salinity gradients in coastal Louisiana. J World Aquacult Soc 21(2):105-115

Gee JM. Maddock L, Davey JT (1977) The relationships between infestation by Mytilicola intestinalis Steur (Copepoda: Cyclopoidea) and the condition index of Mytilus edulis in South West England. J Cons Int Explor Mer 37(3): 300-308

Granovitch Al (1992) The effect of trematode infection on the population structure of Littorina saxatilis Olivi in the White Sea. In: Grahame J, Mill PJ, Reid DG (eds) Proc 3rd Int Symp Littorinid Biology, Dale Fort, Wales. Malacological Soc, London, p 255-263

Grant J, Thorpe B (1991) Effects of suspended sediment on growth, respiration and excretion of the soft-shell clam (Mya arenaria). Can J Fish Aquat Sci 48:1285-1292

Grant WS, Cherry MI (1985) Mytilus galloprovincialis Lmk. in Southern Africa. J Exp Mar Biol Ecol 90:179-191

Griffiths CL, Hockey PAR, van Erkom Schurink C, le Roux PJ (1992) Marine invasive aliens on South African shores: implications for community structure and trophic functioning. S Afr J Mar Sci 12:713-722

Hawkins AJS, Salkeld PN, Bayne BL, Gnaiger E, Lowe DM (1985) Feeding and resource allocation in the mussel $M$. edulis: evidence for time-averaged optimization. Mar Ecol Prog Ser 20:273-287

Hengeveld R (1989) Dynamics of biological invasions, 1st edn. Chapman and Hall, London

Hepper BT (1955) Environmental factors governing the infection of mussels, Mytilus edulis, by Mytilicola intestinalis. Fish Invest Ser II Mar Fish GB Minist Agric Fish Food 20: $2-21$

Hockey PAR, Van Erkom Schurink C (1992) The invasive biology of the mussels Mytilus galloprovincialis on the Southern African coast. Trans R Soc S Afr 48(1):123-139

Howell M (1967) The trematode, Bucephalus longicornutus (Manter 1954) in the New Zealand mud-oyster, Ostrea lutaria. Trans R Soc NZ 8(22):221-237

Huxham M, Raffaelli D, Pike A (1993) The influence of Cryptocotyle liagua (Digenea: Platyhelminthes) infections on the survival and fecundity of Littorina littorea (Gastropoda: Prosobranchia); an ecological approach. J Exp Mar Biol Ecol 168:223-238

Ishak MM, Mohamed AM, Wafa A, Mousa AH, Ayad N (1970) Physiological studies on Biomphalaria alexandrina and Buinus truncatus the snail vectors of Schistosomiasis. I. Oxygen consumption. Hydrobiologia 35:333-344

Jokela J, Votila L, Taskinen J (1993) Effect of the castrating trematode parasite Rhipidocotyle fennica on energy allocation of fresh-water clam Anodonta piscinalis. Funct Ecol $7: 332-338$

Jonsson R, Andre C (1992) Mass mortality of the bivalve Cerastoderma edule on the Swedish west coast caused by infestation with the digenean trematode Cercaria cerastodermae. Ophelia 36(2):151-157

Kautsky N (1982) Growth and size structure in a Baltic Mytilus edulis population. Mar Biol 68:117-133 
Kent RML (1979) The influence of heavy infestations of Polydora ciliata on the flesh content of Mytilus edulis. J Mar Biol Assoc UK 59:289-297

Kinne O (1983) Introduction to Volume Il. In: Kinne O (ed) Diseases of marine animals, Vol II. Biologische Anstalt Helgoland, Hamburg

Kiorboe T, Mohlenberg F, Nohr O (1980) Feeding, particle selection and carbon absorption in Mytilus edulis in different mixtures of algae and resuspended bottom material. Ophelia 19:193-205

Kuris AM (1974) Trophic interactions: similarity of parasitic castrators to parasitoids. Q Rev Biol 49:129-148

Lasiak T (1989) The prevalence of Proctoeces (Trematoda: Fellodistomidae) metacercarial infections in the brown mussel Perna perna (Bivalvia: Mytilidae) around the southern African coast. S Afr J Zool 24:178-186

Lauckner G (1983) Diseases of mollusca. In: Kinne O (ed) Diseases of marine animals, Vol II. Biologische Anstalt Helgoland, Hamburg, p 632-731

Lauckner $G$ (1986) Ecological effects of larval trematode infestations on littoral marine invertebrate populations. Int J Parasitol 17:391-398

Macdonald IAW, Kruger FJ, Ferrar AA (eds) (1986) The ecology and management of biological invasions in southern Africa. Oxford University Press, Cape Town

Marshall DJ, McQuaid CD (1993) Differential physiological and behavioural responses of the intertidal mussels, Choromytilus meridionalis ( $\mathrm{Kr}$.) and Perna perna L. to exposure to hypoxia and air: a basis for spatial separation. J Exp Mar Biol Ecol 171:225-237

May RM, Anderson RM (1978) Regulation and stability of host-parasite population interactions. II. Destabilizing processes. J Anim Ecol 47:249-267

McQuaid CD (1994) Feeding behaviour and selection of bivalve prey by Octopus vulgaris Cuvier. J Exp Mar Biol Ecol 177:187-202

Meakins RH (1980) Studies on the physiology of the snail Biomphalaria glabrata: effects of body size, temperature and parasitism by sporocysts of Schistosoma mansoni upon respiration. Comp Biochem Physiol 66A:137-140

Meuleman EA (1972) Host-parasite interrelationships between the freshwater pulmonate Biomphalaria pfeifferi and the trematode Schistosoma mansoni. Neth J Zool 22(4):355-427

Meyhofer E (1985) Comparative pumping rates in suspension-feeding bivalves. Mar Biol 85:137-142

Mooney HA, Drake JA (1986) Ecology of biological invasions of North America and Hawaii. Ecological series. SpringerVerlag, New York

Navarro E, Iglesias JIP, Perez Camacho A, Labarta U (1991) The physiological energetics of mussels (Mytilus galloprovincialis Lmk.) from different cultivation rafts in the Ria de Arosa (Galicia, NW Spain). Aquaculture 94 $197-212$

Navarro JM, Winter JE (1982) Ingestion rate, assimilation efficiency and energy balance in Mytilus chilensis in relation to body size and different algal concentrations. Mar Biol $67: 255-266$

Newell RIE, Barber BJ (1988) A physiological approach to the study of bivalve molluscan diseases. Am Fish Soc Spec Publ 18:269-280

Norberg JO, Tedengren M (1995) Attack behaviour and predatory success of Asterias rubeus L. related to differences in site and morphology of the prey mussel Mytilus edulis L. J Exp Mar Biol Ecol 186:207-220

Page HM, Hubbard DM (1987) Temporal and spacial patterns of growth in mussels Mytilus edulis on an offshore plat. form: relationships to water temperature and food availability. J Exp Mar Biol Ecol 111:159-179

Pekkarinen M (1991) Notes on the general condition of Mytilus edulis off the southwestern coast of Finland. Bivalve Stud Finland 1:20-40

Pekkarinen M (1993) Bucephalid trematode sporocysts in brackish-water Mytilus edulis, new host of a Helicosporidium sp. (Protozoa: Helicosporida). J Invertebr Path 61 $214-216$

Phillips TE (1994) Dispersal, settlement and recruitment: their influence on the population dynamics of intertidal mussels. PhD dissertation, Rhodes University, Grahamstown

Poulin R (1994) Meta-analysis of parasite-induced behavioural changes. Anim Behav 48:137-146

Pregenzer C (1981) The effect of Pinnotheres hickmani on the meat yield (condition) of Mytilus edulis measured several ways. Veliger 23:250-253

Price PW, Westoby M, Rice B, Atstatt PR, Fritz RS, Thompson JN, Mobley K (1986) Parasite mediation in ecological interactions. Annu Rev Ecol Syst 17:487-505

Ramakrishnan PS (1991) Ecology of biological invasion in the tropics. International Scientific Publications, New Delhi

Ramakrishnan PS, Vitousek PM (1989) Ecosystem-level processes and the consequences of biological invasions. In Drake JA, Mooney HA, di Castri F, Groves RH, Kruger FJ Rejmanek $M$, Williamson $M$ (eds) Biological invasions: a global perspective. SCOPE 37 John Wiley and Sons, Chichester, p 281-300

Richardson CA, Seed R, Naylor E (1990) Use of internal growth bands for measuring individual and population growth rates in Mytilus edulis from offshore production platforms. Mar Ecol Prog Ser 66:259-265

Rodhouse PG, Roden CM, Burnell GM, Hensey MP, McMahon T, Ottway B, Ryan TH (1984) Food resource, gametogenesis and growth of Mytilus edulis on the shore and in suspended culture: Killary Harbour, Ireland. J Mar Biol Assoc UK 64:513-529

Scott ME, Anderson RM (1984) The population dynamics of Gyrodactylus bullatarudis (Monogenea) within laboratory populations of the fish host Poecilia reticulata. Parasitology 89:159-194

Seed R, Suchanek TH (1992) Population and community ecology of Mytilus. In: Cosling (eds) The mussel Mytilus: ecology, physiology, genetics and culture. Elsevier Science Publishers B.V., Amsterdam, p 87-169

Sluiters JF (1981) Development of Trichobilharzia ocellata in Lymnaea stagnalis and the effects of infection on the reproductive system of the host. Z Parasitenkd 64:303-319

Sousa WP (1983) Host life history and the effect of parasitic castration on growth: a field study of Cerithidea californica Haldeman (Gastropoda: Prosobranchia) and its trematode parasites. J Exp Mar Biol Ecol 73:273-296

Sukhotin AA, Kulakowski EE (1992) Growth and population dynamics in mussels (Mytilus edulis L.) cultured in the White Sea. Aquaculture 101(1-2):59-73

Theisen BF (1987) Mytilicola intestinalis and the condition of its host Mytilus edulis. Ophelia 27(2):77-86

van Erkom Schurink C, Griffiths CL (1990) Marine mussels of southern Africa - their distribution patterns, standing stocks, explontation and culture. J Shellfish Res 9:75-85

van Erkom Schuring C Griffiths CL (1991) A comparison of reproductive cycles and reproductive output in four southern African mussel species. Mar Ecol Prog Ser 76:123-134

van Erkom Schurink C. Griffiths CL (1992) Physiological energetics of four South African mussel species in relation to body size, ration and temperature. Comp Biochem Physiol 101:779-789 
van Erkom Schurink C, Griffiths CL (1993) Factors affecting relative rates of growth in four South African mussel species. Aquaculture 109:257-273

Walne PR (1970) The seasonal variation of meat and glycogen content of seven populations of oysters Ostrea edulis L. and a review of the literature. Fish Invest Ser ll Mar Fish GB Minist Agric Fish Food 26:1-35

Walne PR (1972) The influence of current speed, body size and water temperatures on the filtration rate of five species of bivalves. J Mar Biol Assoc UK 52:345-374

Ward JE, Langdon CJ (1986) Effects of the ectoparasite Boonea (=Odostomia) impressa (Say) (Gastropoda: Pyramidellidae) on the growth rate, filtration rate and valve movements of the host Crassostrea virginica (Gmelin). J Exp Mar Biol Ecol 99:163-180

Wesenberg-Lund $C$ (1934) Contributions to the development of the Trematoda Digenea. Part II. The biology of the freshwater cercariae in Danish freshwaters. K Dan Vidensk Selsk Biol Skr 5:1-223

Widdows J, Page DS (1993) Effects of Tributyltin and Dibutyltin on the physiological energetics of the mussel,

Editorial responsibility: Otto Kinne (Editor), Oldendorf/Luhe, Germany
Mytilus edulis. Mar Environ Res 35:233-249

Williams CL, Gilbertson DE (1983) Effects of alterations in the heartbeat rate and locomotor activity of Schistosoma mansoni-infected Biomphalaria glabrata on cercarial emergence. J Parasitol 69(4):677-681

Williams H, Jones A (1994) Parasitic worms of fish, 1st edn. Taylor and Francis L.td, London

Wilson RA, Denison J (1980) The parasitic castration and gigantism of Lymnaea truncatula infected with the larval stages of Fasciola hepatica. Z Parasitenkd 61:109-119

Winter JE (1973) The filtration rate of Mytilus edulis and its dependence on algal concentration, measured by a continuous automatic recording apparatus. Mar Biol 22:317-328

Wright CA (1971) Flukes and snails, 1st edn. Allen and Unwin Ltd, London

Zar JH (1984) Biostatistical analysis, 2nd edn. Prentice Hall, Upper Saddle River, NJ

Zuk M (1987) The effects of gregarine parasites on longevity, weight loss, fecundity and developmental time in the field crickets Grillus veletis and $G$. pennsylvanicus. Ecol Entomol 12:349-354

Submitted: July 4, 1997; Accepted: December 16, 1997

Proofs received from author(s): July 13, 1998 